\section{Summary of Temperature Stress Issues in Nursery Containers and Current Methods of Protection}

\author{
Hannah M. Mathers ${ }^{1}$
}

\begin{abstract}
Additional INDEX WORDs. cold stress, container production, heat stress, nursery, retractable roof greenhouses, pot-in-pot
\end{abstract}

\begin{abstract}
Summary. Container nurseries are generally more productive than field nurseries because plants can be produced faster and at higher densities. Increasingly, nursery stock is being propagated, grown, and marketed in containers. The prime biological advantage of container stock over bareroot and field-grown balled and burlapped $(B \& B)$ stock is that the root system is packaged and protected from transplant or mechanical stress; however, temperature stress limits container production. Plants overwintered in containers suffer greater winter injury than those in the ground because the roots are surrounded by cold, circulating air rather than the insulating environment of the soil. There are several methods for providing protection from cold winter temperatures that are used in the nursery industry; however, all are labor intensive, expensive and vary in effectiveness. Container stock also suffers from elevated summer root zone temperatures. Cultivar differences in the degree of summer injury have been reported. With increasing human population pressures and decreasing availability of fresh water supplies, the need for more water-efficient nursery cultural practices becomes increasingly important. Water and nutrient use efficiency are predominant factors restricting nursery container production. Cultural factors that improve root function and reduce root injury and container heat load are considered
\end{abstract}

Department of Horticulture and Crop Science, Ohio State University, Columbus, OH 43210-1096.

Salaries and research support provided by state and federal funds appropriated to the Ohio Agricultural Research and Development Center, The Ohio State University. Received for publication $07 / 07 / 2003$ Manuscript number HCS 02-25. I acknowledge the technical assistance provided by James Beaver and Jenny Pope in the preparation of this manuscript. key to improving these efficiencies. This paper examines temperature stress issues and the effects of different nursery cultural environments such as conventional overwintering systems, conventional gravel production surfaces, pot-in-pot production, and retractable roof greenhouses.

\section{$\mathrm{T}$} he prime biological advantage of container stock over bareroot stock is that the root system is packaged and protected from transplant and mechanical stress. However, cultivar differences in susceptibility to winter injury (Johnson and Havis, 1977) and summer injury (Jull et al., 1999; Ranney and Peet, 1994) in container-produced stock have been reported (Johnson and Havis, 1977). Responses of cultivars to different cultural practices and production environments could help us to determine methods for predicting the factors that influence root and shoot susceptibility to temperature stress and help reduce winter and summer root kill in container nursery production.

With increased production of container-grown nursery crops, root hardiness has become one of the most important factors determining winter (Johnson and Havis, 1977) and summer (Sibley et al., 1999) survival. Commercial distribution in horticultural crops is usually limited by inadequate vegetative tissue hardiness (Quamme et al., 1982). Limits in the commercial range of ornamental production are becoming associated with lack of root hardiness in winter and lack of heat tolerance of roots in summer. Nursery growers are interested in knowing more about root winter hardiness and summer root heat tolerance levels and how to reduce winter and summer root kill in container production.

Lyr and Hoffmann (1967) proposed that the cold hardiness of shoots is of little importance in determining the natural tree line in northern regions. They suggested that the real factor determining site tolerance for a species is soil temperature. Insufficient root activity as a consequence of low soil temperature would limit northern growth, because plants suffer from desiccation due to high transpiration and limited water uptake. Many container grown plants that have hardy shoots may not have sufficient root hardiness to survive in the zones listed for their shoots, unless they are well protected
(Mathers, 2000). Many studies of root hardiness of numerous woody plants have demonstrated that the root system is substantially less hardy than that of the shoot system (Weist and Steponkus, 1977). As a model, the stems of pyracantha (Pyracantha spp.) are hardy to $-14{ }^{\circ} \mathrm{F}\left(-25.6^{\circ} \mathrm{C}\right)$ whereas the mature roots are injured at temperatures of $-2{ }^{\circ} \mathrm{F}\left(-18.8^{\circ} \mathrm{C}\right)$ and the young roots are only hardy to 21 ${ }^{\circ} \mathrm{F}\left(-6.1{ }^{\circ} \mathrm{C}\right)$ (Steponkus, 1976).

Heat stress also can be a major limiting factor in the distribution, adaptability and productivity of wild and cultivated plants. Inhibition of growth or plant decline under supraoptimal temperatures can result from thermal effects on many physiological and developmental processes (Fitter and Hay, 1987). Net photosynthesis in particular, is one of the most heatsensitive processes that govern plant growth (Ranney and Peet, 1994). Heat stress has been shown to be a major limiting factor for plant production and adaptability in containers (Appleton, 2001; Martin et al., 1989; Sibley et al., 1999). High root zone temperatures are of greater concern than low temperatures to nursery growers, as numerous overwintering strategies exist for dealing with container grown plants (Appleton, 2001). Elevated root-zone temperature below a critical killing threshold can alter plant source-sink relationships and carbon portioning (Martin et al.,1989). It has been noted by several researchers that minimizing root zone temperatures and exposure to direct solar radiation should be considered by nursery operators especially in the southern states and when producing trees (Martin et al., 1989; Martin and Ingram, 1991; Martin and Ruter, 1996; Sibley et al., 1999; Schluckebier and Martin, 1997). Seedlings are especially susceptible to high temperature stress (Columbo and Timmer, 1992; Levitt, 1980).

\section{Abiotic stress and heat shock proteins}

Sixty percent or more of plant samples submitted to plant diagnostic clinics in the U.S. and Canada are abiotic disorders, meaning the causal agent is not alive (Mathers, 1998a). Some common abiotic problems are graft incompatibility, chemical injury, nutritional deficiencies or excesses, excess light or shading, planting too deep, flooding or drought. Mechani- 
Table 1. Effect of stem girdling on the killing point of japanese yew (Taxus cuspidate) young and mature roots (Mityga and Lanphear, 1971).

\begin{tabular}{lcc}
\hline Tissue & \multicolumn{2}{c}{ Killing point $\left({ }^{\circ} \mathbf{F}\right)^{\mathrm{z}}$} \\
\cline { 2 - 3 } type & Nongirdled & Girdled \\
\hline Young roots & 40.0 & 40.0 \\
Mature roots & -9.0 & 22.7 \\
\hline${ }^{20} \mathrm{C}=5 / 9\left({ }^{\circ} \mathrm{F}-32\right)$. & &
\end{tabular}

cal injury due to wind, ice, or other physical factors such as mowers or pollution injuries are also common abiotic problems.

Temperature extremes, either too high or too low, also are a predominant cause of abiotic container injuries. Heat shock proteins (HSPs) form in response to many abiotic stresses: high and low temperatures (Waters et al., 1996), osmotic or salt stress, arsenic, anaerobic conditions, high abscisic acid concentrations, high ethylene levels, high auxin levels, and drought (Vierling, 1991).

HSPs belong to a larger group of molecules called chaperones, which have a role in stabilizing other proteins. Low molecular weight HSPs are generally produced only in response to environmental stress and little was known about their function (Howarth and Ougham, 1993) until 1998. Heckathorn et al. (1998) found that HSPs are involved in protecting Photosystem II during exposure to high temperatures. Heckathorn et al. (1998) showed that whole-chain electron transport was greater in preheat stressed plants relative to controls at $117^{\circ} \mathrm{F}\left(47.2^{\circ} \mathrm{C}\right)$, which indicates that acclimation to high temperatures occurred in pre-heat stressed plants. This acclimation appeared to be the result of production of low molecular weight HSPs.

\section{Winter root hardiness}

Soil or substrate temperature is a very important factor in the growing of woody plants. A plant cannot be any hardier than its roots. If the roots are unable to endure the temperatures to which they are subjected, the plant cannot survive no matter how hardy the shoots may be (Patterson, 1936). Much of the mortality above ground occurring in woody plants is considered the result of root death (Wildung, 1968). Mityga and Lanphear (1971) proposed that only mature roots could harden because the high levels of gibberellins produced in root tips of the young roots nullified the effect of the growth regulator. Research by Mityga and Lanphear (1971) indicated that some promoter from the top of the plant, exposed to short days, translocates to the roots enhancing mature root hardiness. If the phloem of the stem was girdled, the movement of the promoter was blocked and the mature roots did not acclimate (Table 1) (Mityga and Lanphear, 1971).

Root hardiness studies generally indicate that mature root hardiness values are several degrees lower than for the young roots (Borland, 1989; Lindstrom and Mattsson, 1989; Mityga and Lanphear, 1971; Steponkus, 1976; Studer et al., 1978) (Table 2). In many cases, mature roots may survive even when young roots are killed. Knowledge of root hardiness values allows the grower to know what type of overwintering system is necessary to provide sufficient protection for the plants. Injury to young roots, but not mature climation (Studer et al., 1978). roots, explains why some plants flush much later than normal in the spring, show retarded growth throughout the growing season (Gouin, 1974) and may become susceptible to root rot or other disease pathogens. Young roots are often on the outside edge of the container and the first to be injured by cold temperatures.

Only young root tips in which the cell walls are still unsuberized absorb calcium. Calcium $(\mathrm{Ca})$ is required for cell division and elongation. Calcium occurs in considerable quantities in cell walls as calcium pectate and apparently influences cell wall elasticity. Because of its role in the cell wall there is some evidence that it has a role in disease resistance. Injury to young roots can result in a Catch 22 in nursery culture, or a situation where there is no means of escape from the dilemma. Ca is necessary for young root formation but young roots are required for the Ca uptake. Once young roots are injured it is hard to correct the problem of young root regeneration, plants flush later, show retarded growth, etc. Overwintering practices need to be sufficient to protect mature and young roots from injury.

Container plants that have been overwintered without adequate protection of all the roots may leaf out, but

Table 2. Relative hardiness ratings of young and mature roots of selected woody ornamental plants based on killing point determinations following artificial ac-

\begin{tabular}{|c|c|c|}
\hline $\begin{array}{l}\text { Common name } \\
\text { (scientific name) }\end{array}$ & $\begin{array}{l}\text { lling point } \\
\text { of young } \\
\text { oots }\left({ }^{\circ} \mathrm{F}\right)^{\mathrm{z}}\end{array}$ & $\begin{array}{l}\text { Killing point } \\
\text { of mature } \\
\text { roots }\left({ }^{\circ} \mathrm{F}\right)\end{array}$ \\
\hline Flowering dogwood (Cornus florida) & 21 & 10 \\
\hline Bearberry cotoneaster (Cotoneaster dammeri) & 23 & 18 \\
\hline Bearberry cotoneaster ( Cotoneaster dammeri) 'Skogholm' & 19 & 12 \\
\hline Winged euonymus (Euonymus alatus) 'Compacta' & 19 & 7 \\
\hline Wintercreeper (Euonymus fortunei) 'Vegetus' & 23 & 12 \\
\hline Spreading euonymus (Euonymus kiautschovicus) & 21 & 16 \\
\hline St. Johnswort (Hypericum spp.) & 23 & 18 \\
\hline Meserve holly (Ilex $\times$ meserveae) 'Nellie R. Stevens' & 23 & 14 \\
\hline Chinese holly (Ilex cornuta) 'Dazzler' & 25 & 18 \\
\hline Japanese holly (Ilex crenata) 'Helleri' & 23 & 18 \\
\hline American holly (Ilex opaca) & 23 & 9 \\
\hline Aquipernyi holly (Ilex $\times$ aquipernyi) 'San Jose' & 21 & 18 \\
\hline Meserve holly (Ilex $\times$ meserveae $)$ 'Blue Boy' & 23 & 9 \\
\hline Shore juniper (Juniperus conferta) & 12 & $>-9$ \\
\hline Creeping juniper (Juniperus horizontalis) 'Plumosa' & 12 & -4 \\
\hline Blue juniper (Juniperus squamata) 'Meyeri' & 12 & -1 \\
\hline Golden raintree (Koelventeria paniculata) & 16 & -4 \\
\hline Star magnolia (Magnolia stellata) & 21 & 9 \\
\hline Leatherleaf mahonia (Mabonia bealei) & 25 & 12 \\
\hline Scarlet fire thorn (Pyracantha coccinea) 'Lalandei' & 25 & 18 \\
\hline Cutleaf stephanandra (Stephanandra incisa) 'Crispa' & 18 & -1 \\
\hline Anglojap yew (Taxus $\times$ media) 'Hicksii' & 18 & -4 \\
\hline Doublefile viburnum (Viburnum plicatum var. tomentosum) & ) 19 & 7 \\
\hline
\end{tabular}


will wilt and desiccate later in the summer. Common winter injury problems found in inadequately overwintered container stock are bark splitting, root kill, and collar injury (Mathers, 1998b). Bark splitting is common on thin-barked trees. It results from very cold temperatures on sunny days and is often associated with southwest injury (Stushnoffet al., 1985). On sunny days with below freezing temperatures the southwest side of the tree heats up, absorbing the heat of the sun. When the sun sets, or goes behind a cloud, there is a sudden freezing in the heated tissue. A longitudinal crack occurs on the bark of the tree. It also may split the sapwood causing an area of the trunk to dry out and form an awl-shaped scar in the wood. The collar is that portion of the plant where the trunk enters the soil. This region is often the last to harden off in the fall and thus, is susceptible to early freezes (Stushnoff et al., 1985).

For woody plants to develop a maximal degree of cold hardiness, the plants must be fully dormant. Dormancy is induced in response to a shortening photoperiod under warm temperatures (Fuchigami et al., 1982), whereas cold hardiness is induced by exposing dormant trees to cool temperatures. Once the shoots are dormant they cannot regrow until dormancy is broken. Generally, dormancy is broken by providing a given number of chilling units (cool temperatures) and/or heat units (warm temperatures). Richardson et al. (1974) developed the chill unit model widely used today. They determined temperatures between $36.5^{\circ} \mathrm{F}$ $\left(2.50{ }^{\circ} \mathrm{C}\right)$ and $48.4{ }^{\circ} \mathrm{F}\left(9.11^{\circ} \mathrm{C}\right)$ are effective in fulfilling chilling requirements. Fluctuating temperatures are more effective than constant temperatures (Westwood, 1978). Dormancy, however, does not occur in roots (Romberger, 1963). Mature roots can acclimate (Mityga and Lanphear, 1971) but do not enter dormancy. The reasons for not entering dormancy are not known. The roots of woody plants are capable of growth, at any time. Genetic evidence has indicated that a large number of genes are involved in winter dormancy and hence a large number of enzymes and regulating substances also may be involved (Perry, 1971).

\section{Overwintering container stock}

A variety of techniques have been used in the nursery industry to over- winter containers: 1) clear or milky plastic polyethylene (poly) houses or polytents; 2) consolidation, with or without peripheral covering; 3) mass consolidation with a microfoam covering and/or peripheral protection with hay bales; and 4) consolidation with a top covering of polycoated plant foam, white or clear plastic, clear plastic/ straw (the sandwich) (explained below), clear plastic/grass, geotextiles, white plastic/microfilm or microfoam. The amount of protection required depends on the level of root hardiness of the stock being protected. All overwintering methods are generally labor intensive and expensive (Taylor et al., 1983). Overwintering methods not requiring polyhouses are rare even in warmer regions of the U.S. Even in warm regions, only the most cold hardy taxa are not protected in polyhouses. Polyhouses are an integral part of production operations throughout the U.S. (Taylor et al., 1983).

Temperatures within polyhouses are primarily dependent upon the amount of irradiation reaching the houses (Good et al., 1976a). More irradiation means higher temperatures within the structures. Unfortunately, poly does a very poor job of holding heat within polyhouses and tents. On a clear, cold winter day, heat can radiate out of a polyhouse in the late afternoon or early evening as fast as it increases in the morning with the rising sun. Winter night temperatures within polyhouses tend to approach outdoor temperatures even though daytime temperatures within the houses are $20{ }^{\circ} \mathrm{F}\left(11.2^{\circ} \mathrm{C}\right)$ to $30{ }^{\circ} \mathrm{F}\left(16.7^{\circ} \mathrm{C}\right)$ warmer than outdoor temperatures (Good et al., 1976a). Thus, temperatures low enough to cause root injury can occur in polyhouses.

The inability of clear polyhouses to protect roots was shown by Gouin (1974). Two plants coming out of overwintering appeared identical but in the subsequent growing season the root loss to the plant overwintered in a clear polyhouse was evident due to reduced, poor quality top growth. Chong and Desjardines (1981) found little difference between single and double clear polyhouses. Covering the polyhouse with milky poly is the most common technique used to reduce the frequency of high temperatures. In the case of double-layer, air-inflated houses, only one layer of milky poly is necessary. Because of its opaque nature, less light passes through the milky film, and high-temperature build up in structures is minimized (Good et al., 1976b). Polyhouses with microfoam blankets offer better protection and are used in areas where winter temperatures are more severe, but methods conferring less temperature fluctuations and maximum protection have been found for very cold regions such as Minnesota.

Swanson et al. (B.T. Swanson, personal communication) conducted a study to compare two methods for overwintering container stock that were the best from several years of trials. The two methods were white plastic/microfilm (WP/MF) or clear plastic/straw/clear plastic (CP/S/CP) (the sandwich). The temperatures under both coverings were considerably warmer and fluctuated less than ambient temperatures. Air temperatures for 'the sandwich' method averaged $8{ }^{\circ} \mathrm{F}\left(4.4{ }^{\circ} \mathrm{C}\right)$ to $10{ }^{\circ} \mathrm{F}\left(5.6{ }^{\circ} \mathrm{C}\right)$ warmer than the $\mathrm{WP} / \mathrm{MF}$ covering and was more stable in temperature variation. The $\mathrm{CP} / \mathrm{S} / \mathrm{CP}$ sandwich provided the highest minimum, the lowest maximum temperatures and the least fluctuating temperatures under the covering throughout the winter season. They concluded complete protection of container stock can be obtained with a CP/S/CP sandwich if applied to the laid-down stock before severe late fall or early winter freezing temperatures (B.T. Swanson, personal communication) eliminating the need for overwintering polyhouses.

\section{Summer root hardiness}

High root zone temperatures profoundly affect plant growth. Root growth is retarded at temperatures greater than $86{ }^{\circ} \mathrm{F}\left(30.0^{\circ} \mathrm{C}\right)$. Root growth in many woody species stops at temperatures exceeding $103^{\circ} \mathrm{F}(39.4$ ${ }^{\circ} \mathrm{C}$ ) (Johnson and Ingram, 1984). Johnson and Ingram (1984) also noted cessation of top growth and shoot necrosis also occurs at these temperatures. High root zone temperatures can result in reduced photosynthesis. HSPs are involved in protecting photosystem II during heat stress (Heckathorn et al., 1998). Different species within genera have different tolerances to heat (Ranney and Peet, 1994) and different seed provenances within taxa have different heat tolerances. Provenance refers to the geographic origin of the seed. Root zone temperatures of $121{ }^{\circ} \mathrm{F}$ 
$\left(49.4^{\circ} \mathrm{C}\right)$ occur in Florida containers (Ruter, 1989), $122{ }^{\circ} \mathrm{F}\left(50.0{ }^{\circ} \mathrm{C}\right)$ in Oregon (S. E. Svenson, personal communication). Conventional containers in South Carolina commonly reached highs of 90 to $95^{\circ} \mathrm{F}$ (32.2 to 35.0 $\left.{ }^{\circ} \mathrm{C}\right)$ and can reach $110{ }^{\circ} \mathrm{F}\left(43.3^{\circ} \mathrm{C}\right)$ in the container center (London et al., 1998). Temperatures as high as $137^{\circ} \mathrm{F}$ $\left(58.3^{\circ} \mathrm{C}\right)$ have been recorded in containers in southern states (Martin and Ingram 1988; Ruter, 1997a). Normal root functioning ceases when root zone temperatures exceed $96^{\circ} \mathrm{F}\left(35.6^{\circ} \mathrm{C}\right)$ for japanese holly (Ilexcrenata) (Ruter and Ingram, 1992) and at even lower, about $90^{\circ} \mathrm{F}$ for less heat tolerant plants (Levitt, 1980). Substrate temperatures of $138^{\circ} \mathrm{F}\left(58.9^{\circ} \mathrm{C}\right)$ also are reached in Ohio in the center of 1 -gal $(3.8-\mathrm{L})$ containers on gravel beds (D.K. Struve, personal communications).

The importance of keeping container substrate temperatures below $100{ }^{\circ} \mathrm{F}\left(37.8^{\circ} \mathrm{C}\right)$ is well documented. However, as mentioned above, high substrate temperatures in above ground containers in southern and northern states are common. Eastern white cedar (Thuja occidentalis), winged euonymus (Euonymus alatus) and hosta (Hosta spp.) are particularly sensitive to high root temperatures. Dwarf alberta spruce (Picea glanca 'Conica'), can be sensitive to high root zone temperatures when first spaced out in the spring, due to the narrow pyramidal habit of the plant and consequential lack of ability to shade the container. An even browning of foliage over the crown is one way root burn is expressed in dwarf alberta spruce. In above ground containers, roots in the western quadrant of the container are often injured or killed by high temperatures. In pot-in-pot (PIP) systems, roots in the western quadrant were $23{ }^{\circ} \mathrm{F}\left(12.8^{\circ} \mathrm{C}\right)$ cooler than in above ground pots (Ruter, 1997b).

\section{Pot-in-pot and fiber pot production}

In the PIP production system, a planted container is placed in a holder pot that has been permanently placed in the ground (Ruter, 1997b; Mathers, 200la). Growing trees and shrubs in PIP offers a number of production and marketing advantages compared to conventional field production (Ruter, 1997b). PIP was first started in the southern states to protect roots from extreme summer temperatures
(Chong and Mathers 1989), but really caught on in northern states because of the advantages in winter protection (Mathers, 2001a). In conventional container production, winter protection for plant roots is costly and time-consuming. Wind tipping, which is eliminated in PIP, is another timeconsuming, laborious, drawback of conventional container culture. Wind tipping is also detrimental to quality stock production as top-dressed fertilizers and substrate are knocked out of the pot and irrigation applications can be missed or delayed resulting in drought stressed trees. Plants are effectively overwintered in PIP because they are no longer exposed to the cold, circulating air and are protected by the insulating environment of the soil (Mathers, 2001a). Bailey Nurseries in Minnesota is one of the largest growers of PIP in the U.S. In 1999, they placed over 100,000 permanent pots in the ground (Bailey Nurseries, personnel communication).

Plants grown in PIP had 20\% more top growth and nearly twice the root mass compared to conventional container grown plants due to the protection provided from high temperature extremes (London et al., 1998). Cheng et al. (2000) emphasized that plants must be able to photosynthesize and maintain optimum chlorophyll levels to ensure optimum growth and plant health. Plants that experienced high root-zone temperatures suffered loss of chlorophyll and protein production in shoots (Kuroyanagi and Paulsen, 1988). Research indicates that chlorophyll loss has a significant impact on overall plant health (Ruter and Ingram, 1992). Therefore, plants produced in PIP are generally of higher quality than above-ground container produced plants.

The market for this higher quality product, however, has to exist for a nursery business to be successful in selling and recovering the investment cost put into PIP. Estimating 2,400 to 3,000 1-gal containers/acre (5930 to 7,413 containers $/$ ha) at about $4 \times$ $4 \mathrm{ft}(1.2 \mathrm{~m})$ or $3 \times 3 \mathrm{ft}(0.9 \mathrm{~m})$ spacing, leaving room for roadways, at a cost of $\$ 32,000 /$ acre $(\$ 79,071 /$ ha $)$ represents an investment of about $\$ 13.00$ per 15 -gal $(56.8-\mathrm{L})$ pot for the installation of just the holder pots. Additional costs from the moveable or planted pot, media, labor etc. can raise the investment as high as $\$ 20.00$ per 15 gal, not including the plant (Mathers and Zondag, 2002). It is estimated, without complications, it will take about 5 years or 2.5 cycles of product to recoup this up-front investment (Mathers and Zondag, 2002).

Fiber pots, used in the nursery industry for years, especially for seasonal, bare-root crops have recently had copper-based fungicides added to them for increased pot longevity (Ruter, 1999). Fiber pots have many advantages, one being cooling effects for root systems. Overheating in black plastic containers occurs because of the large influx of energy from the sun combined with insufficient loss of the incoming heat (Ruter, 1999). At high temperatures, the membrane integrity of the root is lost and the roots are injured or killed. Conventional plastic containers act as black heat sinks, whereas fiber pots do not (Ruter, 1999). Fiber pots also allow for evaporative cooling through their sides. With fiber containers, some of the absorbed heat is dissipated enough that supraoptimal root-zone temperatures are avoided (Beattie et al., 1999; S.B. Johansen and H.M. Mathers, unpublished). Fiber pots, due to their porous-walls, also increased air exchange throughout the depth of the container, which improves root development by decreasing the potential for water logging (Ruter, 1999).

\section{Retractable roof greenhouses}

With retractable production, the greenhouse roof can be closed in the winter during the day to increase the temperature inside the house. At night, the closed greenhouse roof helps maintain the heat that built up during the day. Adding supplemental heat also can provide warmer temperatures while providing the ability to melt snow off the roof. The main advantage in overwintering lies in the degree of outside exposure allowed to the grower to acclimate plants to the natural environment and the ability to react in minutes to temperature changes to produce hardier crops (Grey, 2001).

The flat roof retractable greenhouses have been installed for nursery stock production in the Pacific northwestern U.S., Texas and the southeastern U.S. Prices for flat-roof houses typically run about $\$ 2.00 / \mathrm{ft}^{2}\left(\$ 21.53 / \mathrm{m}^{2}\right)$ and peaked-roof houses are $\$ 4.00 / \mathrm{ft}^{2}$ $\left(\$ 43.06 / \mathrm{m}^{2}\right)$ (Mathers, 2001b). The peaked-roof curtain houses offer greater flexibility than the flat-roofs 
and are being used in colder climates because the A-frame roof when closed can stand up to inclement weather including heavy snow loads (Grey, 2001). The principal advantage of the flat-roof houses is their reduced cost. Construction of a conventional polyhouses in 1982 was estimated to cost $\$ 0.55 / \mathrm{ft}^{2}$ $\left(\$ 5.92 / \mathrm{m}^{2}\right)$ (Taylor et al., 1983). At 2002 prices for materials and labor this would convert to about $\$ 1.50 / \mathrm{ft}^{2}$ $\left(\$ 16.15 / \mathrm{m}^{2}\right)$. Many Pacific northwestern U.S. nursery growers first started putting up flat-roof houses to replace their current overwintering polyhouse structures. However, with experience they learned their prime advantage was during the growing season in the reduction of supraoptimal root zone temperatures and better light utilization by the crop (Woodburn Nursery and Azaleas, personal communications). In the southeastern U.S. they have been constructed for shade but have resulted in some scorching of crops due to the inability to open far enough for adequate ventilation.

In the Pacific northwestern U.S., Svenson (2000) reported that the retractable roof houses reduce extreme summer temperatures and substrate high temperatures reached in containers grown on gravel beds, via shading. Overheating in black plastic containers occurs because of the large influx of energy from the sun combined with insufficient loss of the incoming heat (Ruter, 1999). In retractable roof production, the roof can be positioned for shading on a hot summer day. The retractable film coverings essentially allow for higher light transmission without the risk of higher soil temperatures. In current nursery culture, black shade cloth is used to reduce light transmission and reduce heat stress to containerized plants. The retractable films allow more light diffusion than conventional polyfilms and more light transmission than black shade clothes without the heat build-up (Svenson, 2000). Cooler substrate temperatures experienced in retractable roof houses protect plant's root from damage, leading to improved shoot growth and reduced substrate evaporation to support transpiration and further growth improvements (Svenson, 2000). Canopy leaves also are cooler under polyfilms with diffuse light, which can increase photosynthetic rates on hot days (Svenson, 2000). Also diffuse light is intercepted more efficiently than direct light leading to increased photosynthetic rates. Due to the protection provided to the root systems and improved photosynthetic capacity of the plants, growers are reporting cutting their production times of certain crops in half.

Growers also reported using half the irrigation water used in conventional container production on outside gravel beds (Woodburn Nursery and Azaleas, personnel communication). This is probably due in part to reduction of supra-optimal root zone temperature injury. Kozlowski and Davies (1975a, $1975 \mathrm{~b}$ ) showed that when many of the small absorbing roots are lost, dehydration stress was intensified with transplanted trees. Root system size is considered one of the more important factors determining a plants ability to tolerate drought (Kramer and Kozlowski, 1979). Generally, cultural practices that reduce root injury and heat load on the container such as shading, using border rows of media filled containers or larger plants to shield inside rows from wind and temperatures, using companion plantings of larger pants to produce an overstory that will shade smaller sized plants in the understory, or using mulches will reduce water use (Davies, 1988)

Retractables also reduce wind throw problems often experienced in conventional above ground container production, and thus fertilizer loss is reduced due to blow-over. Retractableroof greenhouses are being described as a brand new style of growing structure (Grey, 2001). Retractable roof production allows for greater manipulation of the growing environment in winter, summer and spring.

Growers have been reluctant to construct flat roof retractable greenhouses in the Midwest for nursery container production due to concerns of their ability to withstand winter snows and ice. Peaked-roof houses, which could sustain heavy snow loads, are considered too expensive to be used in conventional nursery culture. Nursery growers, however, are starting to use them for higher value items such as tree liner production and perennial production in the midwestern and northeastern U.S. (Mathers et al., 2002).

\section{Impact on nutrition}

The ability to absorb nutrients also is an important component of plant adaptation. Plants have an ideal temperature range for optimum ab- sorption of mineral nutrients (Pisek et al., 1973). Calcium has been found to increase heat tolerance in plants (Bakanova, 1970). However, improper over wintering and supraoptimal root zone temperatures can cause Ca deficiencies due to injury to young roots as discussed above. Plants that are improperly overwintered or experience supraoptimal root zone temperatures show retarded growth throughout the growing season and never catch up with uninjured plants in the production cycle. Young plants require higher levels of available nutrients relative to older plants. Per unit of root system, young plants have the highest nutrient requirements, and nutrient deficiencies are more common with young plants (Mengel and Kirkby, 1987). Therefore, root injuries to young plants are more critical than more mature plants.

Mineralization [i.e., the conversion of organic nitrogen $(\mathrm{N})$ to inorganic $\mathrm{N}$ ] of composted container substrates also is affected by high temperatures (Kraus et al., 2000). Both nitrate $\left(\mathrm{NO}_{3}^{-}\right)$and ammonium $\left(\mathrm{NH}_{4}^{+}\right)$are inorganic forms of $\mathrm{N}$ that can be taken up and metabolized by plants (Mengel and Kirkby, 1987). Nitrate is often a preferential source for plants, but much depends on the plant species and other environmental factors. A number of reports indicate that the uptake of both $\mathrm{N}$ forms is temperature dependent, rates of uptake being depressed by lower temperatures (Clarkson and Warner, 1979).

In general, composts are considered valuable amendments for container substrates. However, most nutrients in compost are not readily soluble and are only released as the organic material breaks down. Most of the $\mathrm{N}$ mineralization studies have been conducted using soil temperatures found in field production. Mineralization of organic $\mathrm{N}$ is microbially mediated and the rate of nutrient availability is regulated by environmental conditions such as temperature, moisture and $\mathrm{pH}$ (Haynes, 1986). Since temperatures of container substrates can reach $103{ }^{\circ} \mathrm{F}$ and above, mineralization rates under these conditions will be quite different from field conditions. Kraus et al. (2000) found that the mineralization rates of certain composted materials in the first weeks of production were too rapid to support adequate $\mathrm{N}$ to maximize growth over the container production season. 


\section{Conclusions}

At the whole plant level, resistance to cold (Cummins and Aldwinckle, 1983 ) and heat are complex quantitatively-inherited characters. Woody plants are characteristically heterozygous and reveal a high variability in hardiness of their seedlings (Stuart, 1941) within species and varieties (Fear et al., 1985; Kaurin et al., 1981) and between tissue types within the plant (Bakradze et al., 1982; Glerum, 1985; Savidge and Wareing, 1982; Weist and Steponkus, 1977). Maturation also influences the cold hardiness level the tissue can attain (Mityga and Lanphear, 1971; Wolpert and Howell, 1986).

Good container media and nutrition management are basic to the production of quality container grown plants (Davidson et al., 2000). The nursery industry is positioned in an environmentally oriented sector, manufacturing the tools that naturally clean up and maintain a healthy environment (Mezitt, 1992). As water resources become scarcer and water quality issues intensify in the U.S., future restrictions on water use and nutrient runoff are imminent. Status quo water and nutrient management, nationally, are no longer good enough. Generally any practice that reduces root injury and heat load on the container will improve water use efficiency for the stock (Davies, 1988).

To minimize environmental impact many growers are using controlled release fertilizers (CRFs) and composted materials. Nutrients generally stimulate or increase the rate of growth in woody plants and thus affect cold hardiness indirectly (Pellet, 1973; Pellet and Carter, 1981). Nitrogen stimulates growth and when applied late in the growing season can prevent growth cessation and thus reduce the potential for cold hardiness in a woody plant(Kelley, 1972). Nielsen(1974) indicated adjustments in amount of water and nutrients supplied could partially ameliorate the affects of unfavorable root-zone temperature. However, Yeager et al. (1991) showed a threshold point was passed at $103^{\circ} \mathrm{F}$. At temperatures above $103^{\circ} \mathrm{F} \mathrm{N}$ accumulations decreased regardless of $\mathrm{N}$ application rate. Research indicates that supplemental fertilizing with water soluble fertilizers, particularly $\mathrm{N}$, is beneficial for fast growing crops when using CRFs, and that composts are good soil amendments for physical properties in containers. However, composts are extremely variable and each should be evaluated before for their chemical and physical properties before use. The effects of fertilizer regimes and growing mediums on acclimation, cold and heat tolerance of roots and impact of potential injury amelioration on water and nutrient use efficiency have not been sufficiently examined in container culture. This is an area of research that will become increasingly crucial as the industry faces further water and nutrient run-off restrictions.

\section{Literature cited}

Appleton, B. 2001. Past and future containers. Nursery Mgt. Prod. 17(10):71-76.

Bakanova, L.V. 1970. Relative heat resistance of leaves and spikelet glumes of certain cereal plants. Soviet Plant Physiol. 17:109-113.

Bakradze, N.G., K.M. Moistrapishvili, and L.V. Keshelasvili. 1982. Effect of plant "hardening" on the crystallization of intracellular water in the tissues. Biophysics 27:736-738.

Beattie, D.J., R. Berghage, V. Puri, and E. Biddinger. 1999. Plant growth thrives on a high-fiber diet. Nursery Mgt. Prod. 15(3):81-83.

Borland, J. 1989. Containers: Beware winter root injury. Landscape Mgt. 28(8): 30-36.

Cheng, L, L.H. Fuchigami, and P.J. Breen. 2000. Light absorption and partitioning in response to nitrogen in apple leaves. J. Amer. Soc. Hort. Sci. 125:581-587.

Chong, C. and R.L. Desjardines. 1981. Comparing methods for overwintering container stock. Amer. Nurseryman 153(1):8-9, 131-135.

Chong, C. and H. Mathers. 1989. Revolutionary Oklahoma technique produces shade trees in two years. Hort. Rev. 7(19): 8-10.

Clarkson, D.T. and A.J. Warner. 1979. Relationships between air temperature and transport of ammonium and nitrate ions by italian and perennial ryegrass. Plant Physiol. 64:557-561.

Columbo, S.J. and V.R. Timmer. 1992. Limits of tolerance to high temperature causing direct and indirect damage to black spruce. Tree Physiol. 11:95-104.

Cummins, J.N. and H.S. Aldwinckle. 1983. Apple rootstock breeding, Plant Breeding Rev. 1:294-394.

Davidson, H., R. Mecklenburg, and C.
Peterson. 2000. Nursery management administration and culture. 4th ed. Prentice Hall, Upper Saddle River, N.J.

Davies, F.T. 1988. Plant water relations: Effect on the growth of woody ornamental plants. J. Rio Grande Valley Hort. Soc. 41:29-31.

Fear, C.D., F.I. Lauer, J.J. Luby, and R.L. Stucker. 1985. Genetic components of variance for winter injury, fall growth cessation, and off-season flowering in blueberry progenies. J. Amer. Soc. Hort. Sci. 110:262-266.

Fitter, A.H. and R.K.M. Hay. 1987. Environmental physiology of plants. $2^{\text {nd }} \mathrm{ed}$. Academic Press, London.

Fuchigami, L.H., C.J. Weiser, K. Kobayashi, R. Timmis, and L.V. Gusta. 1982. A degree growth stage (GS) model and cold acclimation in temperate woody plants, $\mathrm{p}$. 93-116. In: P.H. Li and A. Sakai (eds.). Plant cold hardiness and freezing stress. vol. 2. Academic Press, New York.

Glerum, C. 1985. Frost hardiness of coniferous seedlings: Principles and applications, p. 107-123. In: M.L. Duryea (ed.). Evaluating seedlings: Principles, procedures, and predictive abilities of major tests. Ore. State Univ., Corvallis.

Good, G.L., P.L. Steponkus, and S.C. Weist. 1976a. Using polyhouses for protection. Amer. Nurseryman 144(7): $12,120-125$.

Good, G.L., P.L. Steponkus, and S.C. Weist. 1976b. Cultural factors for overwintering. Amer. Nurseryman 144(8): 14, 117-124.

Gouin, F. 1974. A new concept in overwintering container-grown ornamentals. Amer. Nurseryman 140(11):7-8, 45-47.

Grey, D. 2001. The new retractable-roof greenhouses. Pacific Coast Nurserymen Garden Supply Dealer 60(3):28-30, 41.

Haynes, R.L. 1986. Mineral nitrogen in the plant-soil system. $2^{\text {nd }}$ ed. Academic Press, Orlando, Fla.

Heckathorn, S.A., C.A. Downs, T.D. Sharkey, and J.S. Coleman. 1998 The small, methionine-rich chloroplast heat-shock protein protects Photosystem II electron transport during heat stress. Plant Physiol. 116:439-444.

Howarth, C.J. and H.J. Ougham. 1993. Gene expression under temperature stress. New Phytol. 125:1-26.

Johnson, J.R. and J.R. Havis. 1977. Photoperiod and temperature effects on root acclimation. J. Amer. Soc. Hort. Sci. 102: 306-308.

Johnson, C.R. and D.L. Ingram. 1984. 
Pittosporum tobira response to container medium temperature. HortScience 19: 524-525.

Jull, L.G., T.G. Ranney and F.A. Blazich. 1999. Heat tolerance of selected provenances of atlantic white cedar. J. Amer. Soc. Hort. Sci. 124:492-497.

Kaurin, A., O. Junttila and J. Hansen. 1981. Seasonal changes in frost hardiness in cloudberry (Rubus chamaemorus) as affected by temperature and photoperiod. Physiol. Plant. 52:310-314.

Kelley, J.D. 1972. Nitrogen and potassium rate effects on growth, leaf nitrogen and winter hardiness of Pyracantha coccinea 'Lalandi' and Ilex crenata 'Rotundifolia.' J. Amer. Soc. Hort. Sci. 97:446-448.

Kozlowski, T.T. and W.J. Davies. 1975a. Control of water balance in transplanted trees. J. Arboricult. 1:1-10.

Kozlowski, T.T. and W.J. Davies. 1975b. Control of water loss in shade trees. J. Arboricult. 1:81-90.

Kramer, P.J. and T.T. Kozlowski. 1979. Physiology of woody plants. $1^{\text {st }}$ ed. Academic Press, New York.

Kraus, H.T., R.L. Mikkelsen and S.L. Warren. 2000. Container substrate temperatures affect mineralization of composts. HortScience 35:16-18.

Kuroyanagi, T. and G.M. Paulsen. 1988. Mediation of high-temperature injury by roots and shoots during reproductive growth of wheat. Plant Cell Environ. 11: 517-523.

Levitt, J. 1980. Responses of plants to environmental stresses. vol. 1. $2^{\text {nd }}$ ed. Academic Press, New York.

Lindstrom, A. and A. Mattsson. 1989. Equipment for freezing roots and its use to test cold resistance of young and mature roots of Picea abiesseedlings. Scandinavian J. For. Res. 4:1, 59-66.

London, J.B., R.T. Fernandez, R.E. Young, and J.D. Christenbury. 1998. Media temperatures in above-ground and in-ground pot-in-pot container systems. HortScience 33:512 (abstr.).

Lyr, H. and G. Hoffmann. 1967. Growth rates and growth periodicity of tree roots. Intl. Rev. For. Res. 2:181-236.

Martin, C.A. and D.L. Ingram. 1988. Temperature dynamics in black polycontainers. Proc. S. Nurserymen's Assn. Res. Conf. 33:71-74.

Martin, C.A. and D.L. Ingram. 1991. Evaluation of thermal properties and effect on irrigation on temperature dynamics in container media. J. Environ. Hort. 9: 24-28.
Martin, C.A. and J.M. Ruter. 1996. Growth and foliar nutrient concentrations of crape myrtle in response to disparate climate and fertilizer placement in large nursery containers. J. Environ. Hort. 14:9-12.

Martin, C.A., D.L. Ingram, and T.A. Neil. 1989. Supraoptimal root-zone temperture alters growth and photosynthesis of holly and elm. J. Aboricult. 15(11): 272-276.

Mathers, H.M. 1998a. Monitoring for ornamental pests. Digger 42(12):36-37.

Mathers, H.M. 1998b. Eight types of winter injury. Digger 42(10):44-45.

Mathers, H.M. 2000. Overwintering container nursery stock Part. 1: Acclimation and covering. The Buckeye (Dec.): $14,16,18$.

Mathers, H.M. 200la. Pot-in-pot culture, p. 26-33. In: Western Australian Nut and Tree Crop Association Yearbook 24.2000. Tree Crop Ctr., Perth, Western Austral.

Mathers, H.M. 2001b. The future is in retractables: Nursery stock production in retractable roof greenhouses. The Buckeye (Aug.):16-17,19, 31.

Mathers, H.M. and R. Zondag. 2002. Top 5 pot-in-pot problems. What to avoid, and quick solutions to ease production and improve crops. Nursery Mgt. Prod. 18(7):61 $62,65,66,68,70$.

Mathers, H.M., D. Struve, and A. Stoven. 2002. Tree liner production in Ohio. The Buckeye (Nov.):14-17.

Mengel, K. and E.A. Kirkby. 1987. Principles of plant nutrition. $4^{\text {th }} \mathrm{ed}$. Intl. Potash Inst., Bern, Switzerland.

Mezitt, R. W. 1992. Nursery operator's perspective on water quality impact. HortTechnology 2:82-83.

Mityga, H.G. and F.O. Lanphear. 1971. Factors influencing the cold hardiness of Taxus cuspidata roots. J. Amer. Soc. Hort. Sci. 96:83-86.

Nielsen, K.F. 1974. Roots and root temperatures, p. 293-333. In: E.W. Carson (ed.). Plant root and its environment. Univ. Va. Press, Charlottesville.

Patterson, C.F. 1936. Hardy fruits: With special reference to their culture in western Canada. lst ed. R. and R. Clark, Ltd., Edinburgh, U.K.

Pellett, N.E. 1973. Influence of nitrogen and phosphorus fertility on cold acclimation of roots and stems of two container-grown woody plant species. J. Amer. Soc. Hort. Sci. 98:82-86.

Pellet, H.M. and J.V. Carter. 1981. Nutrition and cold hardiness. Hort. Rev. 3: 144-171.
Perry, T.O. 1971. Dormancy of trees in winter. Science 171:29-36.

Pisek, A., W. Larcher, A. Vegis and K. Napp-Zinn. 1973. The normal temperature range, p. 102-194. In: H. Precht, J. Christophersen, H. Hensel, and W. Larcher (eds.). Temperature and life. Springer-Verlag, New York.

Quamme, H.A., R.E.C. Layne and W.G. Ronald. 1982. Relationship of supercooling to cold hardiness and the northern distribution of several cultivated and native Prunus species and hybrids. Can. J. Plant Sci. 62:137-148.

Ranney, T.G. and M.M. Peet. 1994. Heat tolerance of five taxa of birch (Betula): Physiological responses to supraoptimal leaf temperatures. J. Amer. Soc. Hort. Sci. 119:243-248.

Richardson, E.A., S.D. Seeley, and D.R. Walker. 1974. A model for estimating the completion of rest for 'Redhaven' and 'Elberta' peach trees. HortScience 9:331-332

Romberger, J.A. 1963. Meristems, growth, and development in woody plants. An analytical review of anatomical, physiological, and morphogenic aspects. USDA For. Serv. Tech. Bul. 1293.

Ruter, J.M. 1989. Physiological and biochemical responses of Ilex crenata 'Rotundifolia' to supraoptimal rootzone temperatures. PhD diss. Univ. Fla., Gainesville.

Ruter, J.M. 1997a. Evaluation of Tex-R Agroliners for bag-in-pot production. Proc. S. Nurserymen's Assn. Res. Conf. 42:162-164

Ruter, J.M. 1997b. The practicality of potin-pot. Amer. Nurseryman 8(2):32-37.

Ruter, J.M. 1999. Fiber pots improve survival of 'Otto Luyken' laurel. Proc. S. Nurserymen's Assn. Res. Conf. 44: $53-54$.

Ruter, J.M. and D.L. Ingram. 1992. High root-zone temperatures influence RuBisCo activity and pigment accumulation in leaves of 'Rotundifolia' holly. J. Amer. Soc. Hort. Sci. 117:154-157.

Savidge, R.A. and P.F. Wareing. 1982. Apparent auxin production and transport during winter in the nongrowing pine tree. Can. J. Bot. 60:681-691.

Schluckebier, J.G. and C.A. Martin. 1997. Effects of above-ground pot-in-pot (PIP) placement and Humic acid extract on growth of crape myrtle. J. Environ. Hort. $15: 41-44$.

Sibley, J.L, J.M. Ruter, and D.J. Eakes. 1999. High temperature tolerance of roots of container-grown red maple cultivars. 
Proc. S. Nurserymen's Assn. Res. Conf. 44:24-28.

Steponkus, P.L. 1976. Root hardiness of woody plants. Amer. Nurseryman 144(6): $16,76-79$.

Stuart, N.W. 1941. Cold hardiness of seedlings from certain apple varieties as determined by freezing tests. Proc. Amer. Soc. Hort. Sci. 38:315.

Studer, E.J., P.L. Steponkus, G.L. Good, and S.C. Weist. 1978. Root hardiness of container-grown ornamentals. Factsheet Dept. Floricult. Ornamental Hort., Cornell Univ., Ithaca, NY.

Stushnoff, C., O. Junttila, and A. Kaurin, 1985. Genetics and breeding for cold hardiness in woody plants, p. 141-156 In: A. Kaurin, O. Junttila, and J. Nilsen (eds.). Plant production in the north. Norwegian Univ. Press, Oslo.
Svenson, S.E. 2000. Diffusion confusion: Comparing shade cloth and polyfilm for shading nursery crops. Nursery Mgt. Prod. 16(8):39-44.

Taylor, R.D., H.H. Kneen, D.E. Hahn, and E.M. Smith. 1983. Costs of establishing and operating container nurseries differentiated by size of firm and species of plant in U.S.D.A. climate zone six. S. Coop. Ser. Bul. 301.

Vierling, E. 1991. The roles of heat shock proteins in plants. Annu. Rev. Plant Physiol. Plant Mol. Biol. 42:579-620.

Waters, E.R., G.J. Lee, and E. Vierling. 1996. Evolution, structure and function of the small heat shock proteins in plants. J. Expt. Bot. 47:325-338.

Weist, S.C. and P.L. Steponkus. 1977. Accumulation of sugars and plasmalemma alterations: Factors related to lack of cold acclimation in young roots. J. Amer. Soc. Hort. Sci. 102:119-123.
Westwood, M.N. 1978. Temperate-zone pomology. $1^{\text {st }}$ ed. W.H. Freeman, San Francisco.

Wildung, D.K. 1968. Cold resistance of east malling VII apple rootstock. MSc diss. Univ. Minn., St. Paul.

Wolpert, J.A. and G.S. Howell. 1986. Cold acclimation of Concord grapevines. III. Relationship between cold hardiness, tissue water content, and shoot maturation. Vitis 25:151-9.

Yeager, T.H., R.H. Harrison, and D.L. Ingram. 1991. 'Rotundifolia' holly growth and nitrogen accumulation influenced by supraoptimal root-zone temperatures. HortScience 26:1387-1388. 